\title{
Nitrate uptake by Karenia brevis. II. Behavior and uptake physiology in a nitrate-depleted mesocosm with a bottom nutrient source
}

\author{
Geoffrey A. Sinclair*, Daniel Kamykowski, Edward Milligan, Blake Schaeffer \\ Department of Marine, Earth, and Atmospheric Sciences, North Carolina State University, Campus Box 8208, Raleigh, \\ North Carolina 27695-8208, USA
}

\begin{abstract}
Karenia brevis may optimize growth by alternately maximizing exposure to light, migrating up into an oligotrophic water column during the day, and to nutrients (nitrate), by migrating down to the sediment-water interface at night. Understanding how cell behavior contributes to the acquisition of light and nutrients that are separated in space is critical to understanding how $K$. brevis populations persist in oligotrophic environments. In response to previous modeling efforts that parameterized cell physiology and behavior in nitrate-replete conditions, we examined similar cellular characteristics in a stratified $1.5 \mathrm{~m}$ deep mesocosm. The upper $2 / 3$ of the mesocosm, encompassing the surface and middle samples, was nitrate depleted $\left(<0.5 \mu \mathrm{M} \mathrm{NO}_{3}{ }^{-}\right)$and simulated an oligotrophic water column. The lower $1 / 3$ of the mesocosm contained $10 \mu \mathrm{M} \mathrm{NO}_{3}{ }^{-}$corresponding to elevated nutrient levels near the sediment-water interface. We sampled uptake rates at 3 depths during the day at light levels of 350, 125 and $60 \mu \mathrm{mol}$ quanta $\mathrm{m}^{-2} \mathrm{~s}^{-1}$ and again at night in the dark. Nocturnal uptake of nitrate in the mesocosm was significantly less than diurnal uptake. Nocturnal uptake rates in the mesocom were intermediate between cells exposed to prolonged nitrate-depleted and nitrate-replete conditions. Both migration, as indicated by diel aggregation patterns, and cell physiology indicate that descent to regions of higher nutrient concentrations were sufficient to maintain average growth rates of $0.3 \mathrm{div} \mathrm{d}^{-1}$. Thus, both the physiology and behavior of $K$. brevis may support populations near the sediment-water interface, where they may grow undetected in offshore oligotrophic water columns.
\end{abstract}

KEY WORDS: Karenia brevis · Dinoflagellate $\cdot$ Physiology $\cdot$ Nocturnal uptake $\cdot$ Vertical migration Sediment

\section{INTRODUCTION}

The diel vertical migration of the toxic dinoflagellate Karenia brevis permits access to light and nutrients that may be separated in time and space (Kamykowski \& Yamazaki 1997, Kamykowski et al. 1998b, Yamazaki \& Kamykowski 2000). In the absence of vertical water motion, interactions between behavior and physiology in constantly changing environments determine the distribution and persistence of species in the water column (Cullen 1985). Modeling efforts incorporate the vertical distribution of cells in the water column with hydrographic models in order to predict the transport of cells and ultimately the development and movement of harmful algal blooms (Liu et al. 2001a). Accurate representation of the behavior and physiology of these cells in biophysical models is critical in determining their vertical distribution and subsequent transport trajectories to areas of accumulation.

Due to lack of available information, past models (Liu et al. 2001a,b) were based on experiments that examined cell behavior (Kamykowski et al. 1998a,b), and physiology (Steidinger et al. 1998) in nutrient sufficient environments. But populations of Karenia brevis are often found in oligotrophic water columns 12 to $37 \mathrm{~m}$ deep and 18 to $74 \mathrm{~km}$ offshore (Steidinger \& Haddad 
1981, Tester \& Steidinger 1997, Steidinger et al. 1998). Low concentrations of nitrogen $(\mathrm{N})$ and phosphorus $(\mathrm{P})$ ( 0.1 to $0.2 \mu \mathrm{M}$ ) throughout the water column, including near bottom waters, are commonly observed offshore to within 2 to $4 \mathrm{~km}$ of the shore (Dragovich et al. 1961, Vargo \& Shanley 1985). The sources from which K. brevis may acquire nitrogen include blooms of the $\mathrm{N}$-fixing cyanobacteria Trichodesmium (Walsh \& Steidinger 2001), coastal surface plumes, and offshore, mid-shelf and coastal upwelling (Liu et al. 2001b).

The surface to bottom cell distribution observed by Kamykowski and colleagues in a $22 \mathrm{~m}$ water column during a 2000 ECOHAB cruise (see Sinclair et al. 2006, this volume; their Fig. 1) suggests that another potential source of nitrogen for Karenia brevis is at the sediment-water interface. Each potential nutrient source differs in both its spatial and temporal availability, thus making combinations of nutrient sources optimal for generating red tide events with cell concentrations that exceed 1-2.5 $\times 10^{6}$ cells l$^{-1}$ (Liu et al. 2001a,b).

While no direct measurements were taken of nutrient concentrations associated with the sediments during the ECOHAB 2000 cruise, 30 to $80 \%$ of the microalgal nitrogen requirement in 5-50 m deep coastal environments is met by seepage from the sediments (Nixon 1981, Boynton \& Kemp 1985) and requires further examination. Deposition from blooms of cyanobacteria (Trichodesmium) or phytoplankton may provide organic matter to the sea floor, which is then regenerated as both oxidized and reduced forms that can be assimilated by benthic microalgae (Darrow et al. 2003). The Gulf of Mexico also contains significant sources of freshwater seeps that may be enriched in nitrate relative to the oligotrophic water column (Katz \& Bohlke 2000). Northeastern (Cable et al. 1996, Corbett et al. 1999) and southeastern (Fanning et al. 1987) areas of the Gulf of Mexico contain groundwater seeps that are transported up through the sediment, demonstrated both by geochemical tracers $\left({ }^{222} \mathrm{Rn}\right.$ and $\left.{ }^{226} \mathrm{Ra}\right)$ and by direct measurement with seepage meters (Rutkowski et al. 1999).

If Karenia brevis uses near bottom nutrients, migration behavior, ascending during the day to photosynthesize and descending at night to acquire nutrients (Cullen \& Horrigan 1981, Cullen 1985, Kamykowski et al. 1998b), must be coupled with a cell's physiological capability for nocturnal uptake of nitrate. Numerous studies have documented the periodicity of nitrogen uptake and discussed its ecological relevance to primary production (Eppley et al. 1971, Cochlan et al. 1991). Nitrate uptake in the dark is generally lower than in light (Cochlan et al. 1991) but is thought to increase with the duration of $\mathrm{N}$ deficiency (Harrison 1976). Ascending into an oligotrophic water column during the day may enhance nocturnal uptake to suffi- cient levels to facilitate cell growth. The potential changes in a cell's uptake response over a migration cycle make it necessary to examine the assumptions present in models based on cells conditioned to a single light and nutrient environment (Flynn et al. 2002). Contrary to uptake rates equivalent during the day and night (Liu et al. 2001a), K. brevis exhibits enhanced nocturnal uptake after exposure to $\mathrm{N}$ depleted environments. This study seeks to further refine the uptake parameters in Liu et al. (2001a) by examining how the uptake physiology is coupled to the behavior of $K$. brevis, with particular attention to the half saturation constants and maximal uptake velocities that are used to parameterize the model. Using a mesocosm depleted of nitrate in the upper part of the water column, but with the opportunity to access a bottom nitrate source, we more closely simulate the physical and chemical environment cells encounter in nature.

\section{MATERIALS AND METHODS}

We used a mesocosm to simulate light and nutrient conditions that might be encountered by an offshore, near-bottom population of Karenia brevis, similar to conditions observed on the 2000 ECOHAB cruise. A 2941 mesocosm, $1.5 \mathrm{~m}$ deep $\times 0.5 \mathrm{~m}$ diameter, was used to permit vertical migration of cells (Fig. 1). The mesocosm was filled with $290 \mathrm{l}$ filtered Gulf Stream water (salinity $=35$ ) and modified with L/20 medium with nitrate as the only nitrogen source following the

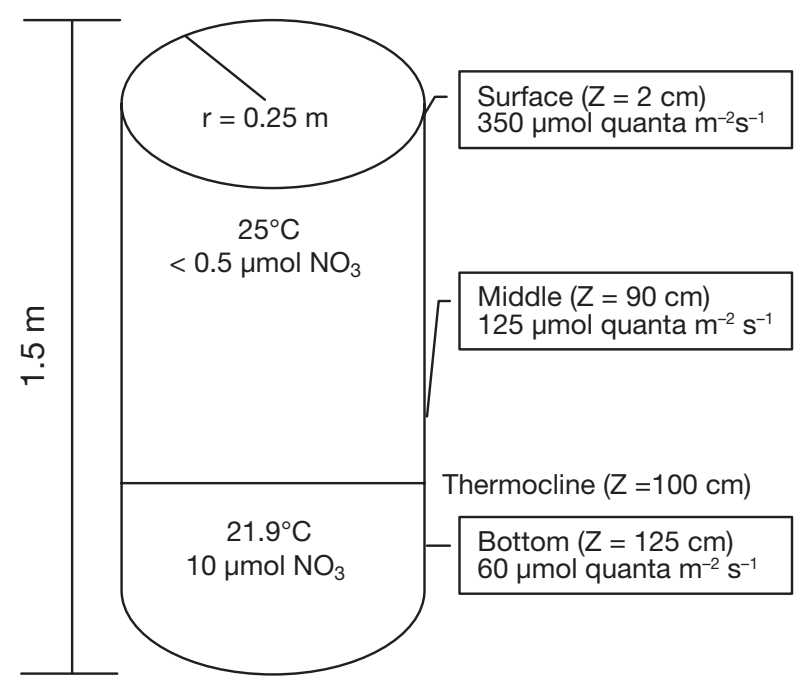

Fig. 1. Schematic of $\left[\mathrm{NO}_{3}{ }^{-}\right]$-stratified mesocosm (vol = 294 l), artificially illuminated from above (12:12 h light:dark cycle). Samples were drawn from each layer (surface, middle, bottom) at 12:30 and 23:00 h. Nitrate nutricline permitted by thermal stratification 
protocol of Sinclair et al. (2006). A 61 batch culture of non-axenic $K$. brevis (strain Apalachicola) grown in similar media was then added to the mesocosm. The culture was grown until near nitrate depletion. In order to simulate the higher nutrient environment presumably encountered by a near-bottom population, the mesocosm was then thermally stratified by holding the lower $0.5 \mathrm{~m}$ at $21.9^{\circ} \mathrm{C}$ and the upper $1 \mathrm{~m}$ at $25^{\circ} \mathrm{C}$. A nutricline was created by slowly inoculating the stable layer below the thermocline with L/20 media with nitrate as the only nitrogen source. The nitrate concentration in the upper $2 / 3$ of the mesocosm was monitored until it was depleted to a level undetectable by either manual analysis or the Lachat Quikchem 8000 Continuum Series Autoanalyzer. This upper layer simulated low nutrient water columns found in the Gulf of Mexico. The lower 1/3 of the mesocosm contained $10 \mu \mathrm{M}$ nitrate, simulating elevated nutrients near the sediment water interface. During the diurnal part of the light cycle, irradiances from an artificial light source at the surface $(\sim 2 \mathrm{~cm})$, middle $(\sim 90 \mathrm{~cm})$ and bottom $(\sim 125 \mathrm{~cm})$ depths were 350,125 and $<60 \mu \mathrm{mol}$ quanta $\mathrm{m}^{-2} \mathrm{~s}^{-1}$, respectively. The culture was grown under these conditions with a 12:12 h light:dark cycle for $1 \mathrm{wk}$ while nutrients were monitored daily. Nutrients below the thermocline were replenished as needed to maintain the nutricline.

Uptake of nitrate by Karenia brevis was examined at the extremes of its diel vertical migration. Nitrate uptake was examined at the 3 depths (surface, middle and bottom) at 12:30 and 23:00 h. In order to help explain differences in nitrate uptake between the 3 depths, indicators of internal nitrogen reserves (intracellular nitrate pools, intracellular free amino acids, and total cellular N) were measured in sub-samples taken at the same time. $50 \mathrm{ml}$ flasks from the surface $(2 \mathrm{~cm})$ and middle $(90 \mathrm{~cm})$ were inoculated with a stock solution of $10 \%\left[{ }^{15} \mathrm{~N}_{\mathrm{NO}_{3}}{ }^{-}\right.$in one of the following concentrations: 0 (control), $0.25,0.5,0.8,1.2,2,4.0,8.0$, or $11.0 \mu \mathrm{M}$. The bottom samples $(125 \mathrm{~cm})$, both at $12: 30 \mathrm{~h}$ and $23: 00 \mathrm{~h}$, were only inoculated with the $11.0 \mu \mathrm{M}$ stock solution containing $20 \%\left[{ }^{15} \mathrm{~N} \mathrm{NO}_{3}{ }^{-}\right.$so that the final percentage of $\left[{ }^{15} \mathrm{~N}_{\mathrm{NO}_{3}}{ }^{-}\right.$was $10 \%$ of the total nitrate in the media of all flasks. The flasks were then incubated under light and temperature conditions similar to those from which they came for 2 hours in a radial photosynthetron as described in Sinclair et al. (2006). A subset from each diurnal treatment was trapped to prevent movement from conditions to which they were exposed during the day in order to act as a control for migration behavior component and more accurately contrast diurnal versus nocturnal nitrate uptake. These samples, referred to as migration control groups, were then inoculated along with the nocturnal treatments. Triplicates of the $0.5 \mu \mathrm{M}$ and $11.0 \mu \mathrm{M}$ incubations were used to determine variability of the technique at high and low nitrate concentrations. All other experimental and statistical analysis performed on triplicate samples followed protocols described in Sinclair et al. (2006).

\section{RESULTS}

\section{Day}

Karenia brevis exhibited a strong surface aggregation with $45400 \pm 1086 \mathrm{cells} \mathrm{ml}^{-1}$ in the upper $2 \mathrm{~cm}$ of the mesocosm at 12:30 h. Cell densities just above the nutricline were about $7900 \pm 240$ cells ml $^{-1}$ while densities below the nutricline were about $15200 \pm 221$ cells $\mathrm{ml}^{-1}$ throughout the lower $25 \mathrm{~cm}$ (Table 1). Cell diameter increased significantly with depth; cells near the surface averaged $19.14 \pm 0.05 \mu \mathrm{m}$, cells in the middle averaged $20.14 \pm 0.05 \mu \mathrm{m}$, and cells near the bottom averaged $20.86 \pm 0.04 \mu \mathrm{m}$. In general, cells above the nutricline were significantly smaller than cells below the nutricline $(F=13.9, \mathrm{p}<0.01)$. Despite differences in cell diameter and external nitrate concentrations, intracellular nitrate level did not vary significantly with depth, even though there appeared to be a decreasing trend (surface $0.03 \pm 0.02 \mathrm{pg} \mathrm{cell}^{-1}$, middle $0.02 \pm 0.02 \mathrm{pg} \mathrm{cell}^{-1}$ and bottom $0.01 \pm 0.006 \mathrm{pg} \mathrm{cell}^{-1}$ )

Table 1. Karenia brevis. Summary of diel patterns in mesocosm: means $( \pm \mathrm{SD})$ of population distribution, cell size, intracellular nitrate $\left(\mathrm{iNO}_{3}{ }^{-}\right)$, intracellular free amino acids (iFAA), total cellular $\mathrm{N}\left(\mathrm{N}_{\text {tot }}\right)$, uptake rate normalized to cell $\mathrm{N}$ inoculated with $11 \mu \mathrm{M}$ nitrate $\left(\mathrm{V}_{11}\right)$ and half saturation constant $\mathrm{K}_{\mathrm{s}} \cdot\left({ }^{*}\right)$ Control treatments

\begin{tabular}{|lcccccccc|}
\hline $\begin{array}{l}\text { Time } \\
(\mathrm{h})\end{array}$ & $\begin{array}{c}\text { Depth } \\
(\mathrm{cm})\end{array}$ & $\begin{array}{c}\text { Cell no. } \\
\left(\mathrm{ml}^{-1}\right)\end{array}$ & $\begin{array}{c}\text { Diameter } \\
(\mu \mathrm{m})\end{array}$ & $\mathrm{iNO}_{3}{ }^{-}$ & $\begin{array}{c}\text { iFAA } \\
\left(\mathrm{pg} \mathrm{cell}^{-1}\right)\end{array}$ & $\mathrm{N}_{\text {tot }}$ & $\begin{array}{c}\mathrm{V}_{11} \\
\left(\mathrm{~h}^{-1}\right)\end{array}$ & $\begin{array}{c}\mathrm{K}_{\mathrm{s}} \\
(\mathrm{pg})\end{array}$ \\
\hline $12: 30$ & 2 & $45400 \pm 1086$ & $19.14 \pm 0.05$ & $0.03 \pm 0.02$ & $0.22 \pm 0.004$ & $108 \pm 16$ & $0.94 \pm 0.04$ & 16 \\
& 90 & $7900 \pm 240$ & $20.14 \pm 0.05$ & $0.02 \pm 0.02$ & $0.24 \pm 0.002$ & $77 \pm 17$ & $0.83 \pm 0.24$ & 3.5 \\
& 125 & $14524 \pm 221$ & $20.86 \pm 0.05$ & $0.01 \pm 0.006$ & $0.37 \pm 0.001$ & $81 \pm 17$ & $0.36 \pm 0.02$ & \\
$23: 00$ & 2 & $5300 \pm 278$ & $19.56 \pm 0.02$ & $0.1 \pm 0.04$ & $0.23 \pm 0.003$ & $104 \pm 7$ & $0.18 \pm 0.07$ & $4.6\left(0.91^{*}\right)$ \\
& 90 & $4200 \pm 241$ & $19.94 \pm 0.07$ & $0.1 \pm 0.03$ & $0.3 \pm 0.09$ & $114 \pm 2$ & $0.22 \pm 0.03$ & $1.4\left(2.8^{*}\right)$ \\
& 125 & $18200 \pm 92$ & $20.67 \pm 0.08$ & $0.02 \pm 0.003$ & $0.33 \pm 0.001$ & $103 \pm 9$ & $0.18 \pm 0.03$ \\
\hline
\end{tabular}


with depth. Intracellular free amino acids varied with depth. Cells from the surface $\left(0.22 \pm 0.004 \mathrm{pg} \mathrm{cell}^{-1}\right)$ and middle $\left(0.24 \pm 0.002 \mathrm{pg} \mathrm{cell}^{-1}\right)$, both in the nutrient depleted layer, had significantly less free amino acids than cells below the nutricline $\left(0.37 \pm 0.001 \mathrm{pg} \mathrm{cell}^{-1}\right.$; $\mathrm{df}=2, t>3.9, \mathrm{p}<0.02$ ). Total cellular nitrogen did not differ significantly with depth though cells at the surface $\left(108 \pm 16 \mathrm{pg} \mathrm{cell}^{-1}\right)$ appeared to contain more $\mathrm{N}$ than cells in the middle $\left(77 \pm 17 \mathrm{pg} \mathrm{cell}^{-1}\right)$ or at the bottom $\left(81 \pm 14 \mathrm{pg} \mathrm{cell}^{-1}\right)$.

Uptake increased with nitrate concentration in both the surface and middle layers (Fig. 2). Comparisons of uptake in high substrate concentrations $(11 \mu \mathrm{M}$ with cells from the surface and middle, and $21 \mu \mathrm{M}$ with cells from the bottom) revealed that cells from both the surface $(F=389, \mathrm{p}<0.01)$ and the middle $(F=11.3, \mathrm{p}=$ 0.02 ) of the mesocosm took up nitrate significantly faster than cells at the bottom (Fig. 2). At high nitrate concentrations $(11 \mu \mathrm{M})$ in the top and middle layers, cells had similar capacities and were capable of replenishing $>90 \%$ of their cellular $\mathrm{N}$ in $1 \mathrm{~h}$. Regressions based on the Michaelis-Menten equation (applicable only in the surface and middle layers) yielded different estimates for uptake rates at $11 \mu \mathrm{M}$ nitrate (Table 1). The difference in these numbers may be due to the uptake of the surface cells not reaching an asymptote at the nitrate concentrations, which would hinder calculation of a true value. Cells from below the nutricline were, in contrast, able to replenish $>30 \%$ of their total cellular $\mathrm{N} \mathrm{h}^{-1}$.

Cells from the middle took up significantly more nitrate $\mathrm{h}^{-1}$ than did cells from the surface when provided with $0.5 \mu \mathrm{M}$ nitrate additions (Fig. 2; $F=13.9$,

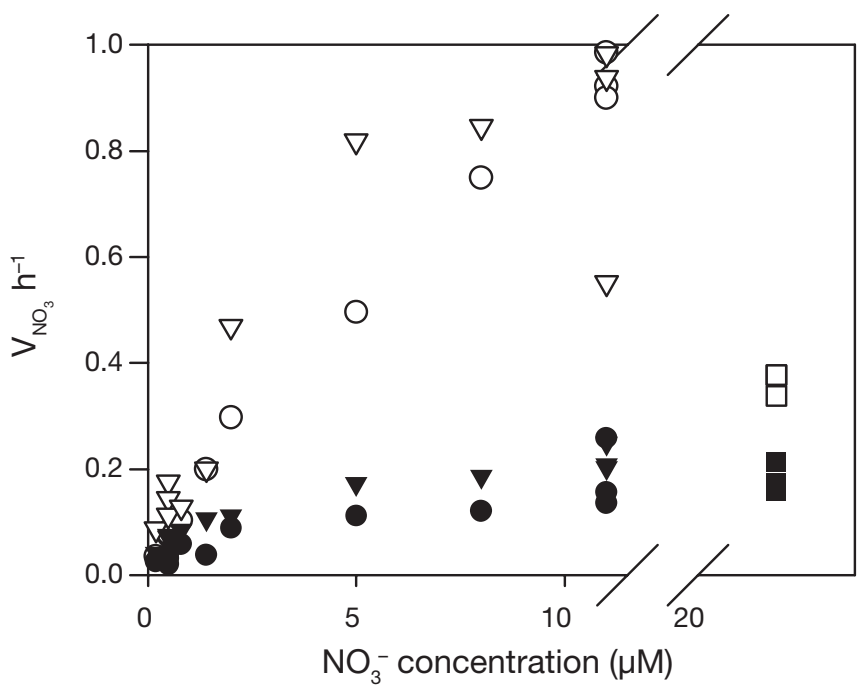

Fig. 2. Karenia brevis. Diurnal (open symbols) vs. nocturnal (closed symbols) nitrate uptake as a function of nitrate concentration from all depths. $(\bigcirc \bullet)$ Surface, $(\nabla \nabla)$ middle, (口ם) bottom $\mathrm{p}=0.02$ ). In $1 \mathrm{~h}$ under these low nitrate concentrations, cells from the middle were able to take up $\sim 15 \%$ of their total cellular $\mathrm{N}$ while cells from the surface only took up $7-8 \%$. The $\mathrm{K}_{\mathrm{s}}$ values derived from the curves likewise indicated that the middle cells had greater affinity (3.5) than did surface cells (16.2) (Table 1).

\section{Night}

The sampling at 23:00 $\mathrm{h}$ showed a distinct increase in cell concentration below the nutricline. The cell concentration at the surface was $5300 \pm 278$ cells ml $^{-1}$, while that in the middle (just above the nutricline) was $4200 \pm 241$ cells ml$^{-1}$. The cell concentration at the bottom (below the nutricline) was $18200 \pm 92 \mathrm{cells} \mathrm{ml}^{-1}$. Cell diameter increased significantly with depth. Cells at the surface $(19.56 \pm 0.02 \mu \mathrm{m})$ and middle $(19.94 \pm$ $0.07 \mu \mathrm{m}$ ) of the mesocosm were significantly smaller on average than cells at the bottom $\left(20.67 \pm 0.08 \mu m_{i}\right.$ $F=19.6, \mathrm{p}<0.01$.

Patterns in vertical distribution of the intracellular nitrate pools differed markedly from those observed during the day. Cells in the nitrate-depleted media above the nutricline, both at the surface $\left(0.1 \pm 0.04 \mathrm{pg} \mathrm{cell}^{-1}\right)$ and in the middle $\left(0.1 \pm 0.03 \mathrm{pg}\right.$ cell $\left.^{-1}\right)$, had significantly greater intracellular nitrate pools than cells below the nutricline $\left(0.02 \pm 0.003 \mathrm{pg} \mathrm{cell}^{-1} ; \mathrm{df}=2, t=11.5, \mathrm{p}<0.04\right.$ and $\mathrm{df}=2, t=5.7, \mathrm{p}=0.01$ respectively). Levels of intracellular free amino acids tended to increase with depth, but the only significant difference was that cells at the surface $\left(0.23 \pm 0.003 \mathrm{pg} \mathrm{cell}^{-1}\right)$ had fewer free amino acids than cells at the bottom $\left(0.33 \pm 0.001 \mathrm{pg} \mathrm{cell}^{-1} ; \mathrm{df}=\right.$ $2, t=3.2, \mathrm{p}=0.03)$. Total cellular $\mathrm{N}$ did not vary significantly with depth.

Nocturnal uptake of nitrate increased with nitrate concentration at a given depth but did not differ between the 3 depths in the $11 \mu \mathrm{M}$ incubations (Fig. 2). Cells at all levels were able to take up at least $18 \%$ of their total cellular $\mathrm{N}$ in $1 \mathrm{~h}$ at $11 \mu \mathrm{M}$. Cells from the surface and middle were able to take up a maximum of 22 and $18 \%$ of the total cellular $\mathrm{N}$ of the cell in $1 \mathrm{~h}$ (Table 1). Similar values may be inferred for the bottom cells since uptake rates of all groups in the $11 \mu \mathrm{M}$ additions were similar.

Cells from the middle took up significantly more nitrate in the $0.5 \mu \mathrm{M}$ additions than did cells from the surface $(F=63.2, \mathrm{p}<0.01)$. In $1 \mathrm{~h}$, cells in the middle of the mesocosm were able to take up $\sim 7 \%$ of their intracellular $\mathrm{N}$ while surface cells were only able to take up $\sim 3 \%$. There was no significant difference in the rate of nitrate uptake between depths in the $11 \mu \mathrm{M}$ incubations. The affinity of cells from the surface was less than that of those from the middle $\left(\mathrm{K}_{\mathrm{s}}=4.62\right.$ and $1.43 \mu \mathrm{M}$ respectively, Table 1 ). 
The migration control groups from each depth (surface and middle), trapped during the day and incubated at night, did not show any apparent differences in uptake rates at $11 \mu \mathrm{M}$ nitrate when compared to the nocturnal samples (Fig. 3). These groups did however show lower $\mathrm{K}_{\mathrm{s}}$ than cells at the surface at night (Table 1).

\section{Day vs. night}

The vertical distribution of cells changed from 12:30 to 23:00 h. The dense surface aggregation found during the day dispersed downward at night with highest concentration at 23:00 $\mathrm{h}$ found below the nutricline. With this redistribution, the average cell size in the surface layer increased significantly $(F=205, \mathrm{p}<0.01)$ and the average cell diameter in the middle and below the nutricline decreased $(F=18.4, \mathrm{p}=0.013 ; F=10.8$, $\mathrm{p}=0.029)$. Intracellular nitrate levels were greater at all depths at 23:00 $\mathrm{h}$ than at $12: 30 \mathrm{~h}(\mathrm{df}=8, t=3.2$, $\mathrm{p}<0.01)$. Intracellular free amino acid content did not differ among cells at the 3 depths. When all depths at $12: 30$ and at 23:00 $\mathrm{h}$ were pooled, the total cellular $\mathrm{N}$ was significantly greater at 23:00 than at $12: 30 \mathrm{~h}$ (df $=8, t=1.9, \mathrm{p}=0.04)$.

Nitrate uptake was significantly greater at $12: 30$ than at 23:00 $\mathrm{h}$ for all depths $(F=20.9, \mathrm{p} \ll 0.01)$ (Fig. 2). Estimates for maximum uptake normalized to cellular $\mathrm{N}$ content indicate that cellular capacity to take up nitrate was about $4.5 \times$ greater during the day than at night (Table 1). Affinity for nitrate was apparently greater at night than during the day; nocturnal $\mathrm{K}_{\mathrm{s}}$ values were lower by a factor of 2 to 4 . The kinetics of nitrate uptake were not measured for the bottom

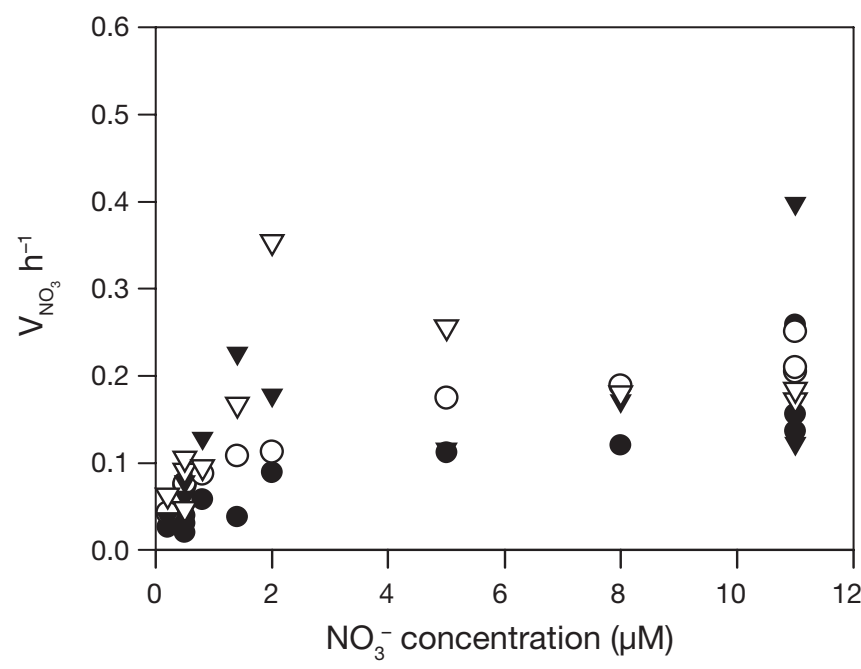

Fig. 3. Karenia brevis. Nocturnal nitrate uptake as a function of nitrate concentration. ( $)$ Surface, $(\boldsymbol{\nabla})$ surface control, (O) middle, $(\nabla)$ middle control population, so comparisons of $\mathrm{K}_{\mathrm{s}}$ values cannot be extended to that layer of the mesocosm.

\section{DISCUSSION}

The migration patterns of cell dispersion from the sediments during the day and cell aggregation near the sediments at night, observed on the ECOHAB 2000 cruise, is supported by the strong diurnal aggregations at the surface of the mesocosm and the subsequent redistribution of cells at night into the nitrate-replete lower layer of the mesocosm. Cell ascent toward greater light intensity during the day and descent at night to nitrate-enriched areas of the mesocosm more closely resembled the patterns observed during the ECOHAB 2000 cruise than previous mesocosm work that supported the modeling efforts of Liu et al. (2001a). The patterns in cell densities also confirm the insignificant effect of the $3.6^{\circ} \mathrm{C}$ thermocline provided here on vertical migration behavior (Kamykowski 1981). Temperature also may not have influenced uptake rates since both temperatures greatly exceeded the temperature optima of nitrate reductase in other phytoplankton species thereby decreasing the enzyme activity in an equivalent manner (Kristiansen 1983).

The parameters of nitrate uptake differed significantly from those used in previous models (Liu et al. $2001 \mathrm{a}, \mathrm{b})$. Liu et al. (2001b) calculated that average uptake rates ranged from $0.122 \mathrm{pmol} \mathrm{N} \mathrm{cell}^{-1} \mathrm{~h}^{-1}$ for the $\mathrm{N}$-replete daughter cell (total cell $\mathrm{N}=23.3 \mathrm{pmol}$ ) to $0.236 \mathrm{pmol} \mathrm{N} \mathrm{cell}^{-1} \mathrm{~h}^{-1}$ for the $\mathrm{N}$-deficient daughter cell (total cell $\mathrm{N}=6.32 \mathrm{pmol}$ ). The average of these rates (0.179 pmol $\mathrm{N} \mathrm{cell}^{-1} \mathrm{~h}^{-1}$ ) was similar to the $0.14 \mathrm{pmol}$ $\mathrm{N}_{\text {cell }}{ }^{-1} \mathrm{~h}^{-1}$ reported previously (Steidinger et al. 1998). While the total cellular $\mathrm{N}$ found in this study was similar to batch experiments presented in Sinclair et al. (2006), both were more similar to the N-deficient daughter cell used in Liu (2001a,b). The minimum uptake rate found in this experiment was still considerably higher $\left(0.96\right.$ pmol $\mathrm{N}$ cell $\left.^{-1} \mathrm{~h}^{-1}\right)$ at night than the $\mathrm{N}$-deficient daughter cell. The maximum uptake rate during the day was about $4.5 \mathrm{pmol} \mathrm{N}$ cell $\mathrm{p}^{-1} \mathrm{~h}^{-1}$ or $90 \%$ of the total cell $\mathrm{N}$. The discrepancies of these rates are most likely due to differences in incubation conditions and the consequential physiological state. The calculated values (Liu et al. 2001a,b) are similar to uptake rates necessary to support growth, which are found in nutrient replete conditions. The results reported here seem more indicative of maximal uptake rates that increase with the previous duration of nutrient stress (Morel 1987). Maximum short-term uptake rates are many times in excess of those values necessary to maintain growth (McCarthy \& Goldman 1979). While this short-term uptake capacity may not be ecologi- 
cally significant in all situations (such as in areas with consistently sufficient nutrient concentrations) it may be relevant to the ecology of Karenia brevis when cells descend from nutrient-deficient parts of the water column to the near-bottom nutrient sources where exposure may be short.

Unlike our companion paper (Sinclair et al. 2006) which suggests that Karenia brevis enhances nocturnal uptake after exposure to $\mathrm{N}$ depleted conditions, cells in this experiment showed a 3 -fold decrease in uptake from day to night in the surface and middle layers, and a 2-fold decrease in the bottom layers. While this is consistent with decreased nitrate uptake rates at night in phytoplankton assemblages (Cochlan et al. 1991) as well as within a species (Clark \& Flynn 2002), this uptake pattern is not consistent with cells migrating up into nitrogen-depleted water for $12 \mathrm{~h}$. The nocturnal uptake rates seen here are intermediate between those uptake rates of $\mathrm{N}$ depleted cells and the uptake rates of cells exposed to nitrogen-sufficient environments prior to the experiment. The scale of the mesocosm may account for the discrepancies in nocturnal uptake. $K$. brevis cells migrating at $1 \mathrm{~m} \mathrm{~h}^{-1}$ in a $1.5 \mathrm{~m}$ mesocosm would be able to migrate into and out of the nitrate-rich bottom layer and maintain an internal cellular nitrogen content more analogous to $\mathrm{N}$ replete cells. This suggests that cells are actively using migration to access the deeper nitrate-rich region of the mesocosm.

While the declining maximum uptake rates of the surface and middle cells demonstrated decreased nocturnal uptake capacity, their nitrate affinities increased at night. The greatly enhanced affinities (decreased $\mathrm{K}_{\mathrm{s}}$ ) of the surface control group (that did not exchange cells with other layers before the nocturnal incubations) relative to those of freely-moving cells sampled at the surface suggest that cells that remained at the surface became increasingly $\mathrm{N}$ deficient throughout the day. The apparent increase in affinity at night in the middle layer may be due to more depleted surface cells dispersing deeper in the mesocosm. Unlike increases in $\mathrm{K}_{\mathrm{s}}$ at night in other dinoflagellates (MacIsaac 1978), Karenia brevis cells may increase the efficiency with which they take up nitrate thereby contributing to the apparent benefit of nocturnal descent. Day versus night differences in uptake kinetics may significantly contribute to cell nutrition if the behavior is a response to internal biochemical state.

The affinities for nitrate found in the upper layer of the mesocosm are not consistent with values reported previously that are characteristic of oligotrophic phytoplankton species (Steidinger et al. 1998) though they are consistent with those of other dinoflagellates (Smayda 1997). The discrepancy may be due to different environmental conditions, different
Karenia brevis strains or to different techniques. The value $\left(\mathrm{K}_{\mathrm{s}}=0.42 \mu \mathrm{M}\right)$ was obtained using the Wilson strain and measuring the disappearance of nitrate from the media (Steidinger et al. 1998).

The differences in affinities for nitrate uptake may not only influence the parameterization of models (Liu et al. 2001a) but the conceptualization of behavior (Liu et al. 2001b). In the latter model, cell behavior was dictated by logical decisions based on the threshold of nitrate $\left(T_{N}\right)$ where $T_{N}=3 \times K_{s}$. Cells descend if $T_{N}<$ $1.26 \mu \mathrm{M}$, otherwise cells rest or ascend. If $\mathrm{K}_{\mathrm{s}}$ changes from day to night or is significantly higher such as those values found in this study, the decreased affinity in cells may alter swimming rules dramatically. This threshold when calculated using affinities found here ranged from 3 to $12 \mu \mathrm{M}$ nitrate. While such low sensitivities may not be realistic in nature, under the model guidelines, cells are much less likely to encounter the given concentrations, and therefore descend until they encounter a strong upwelling plume or the sediment water interface.

Descent to near-bottom nutrient sources coupled with enhanced short term nocturnal uptake may support the slow growth rates of Karenia brevis (Wilson 1966, Shanley \& Vargo 1993) and contribute to population persistence in offshore and oligotrophic water columns. The ability of $K$. brevis to maintain and increase populations undetected near the bottom of the water column in offshore areas permits delivery via upwelling to areas of accumulation, such as thermal or salinity fronts (Reed 2000). More accurate understanding of the physiology and behavior of $K$. brevis in oligotrophic regions and the continued refinement of models will contribute to understanding the development of red tide events near shore.

Acknowledgements. We thank our colleagues in the laboratories of Dr. W. Showers for use of their Lachat Quik Chem Autoanalyzer, Dr. N. Blair for use of the Carlo Erba Nutrient analyzer and the NCSU Soil Science Department for use of their mass spectrophotometer. This paper received significant improvement in response to the comments of 2 anonymous reviewers. This paper is based on research that has been supported in part by the US National Oceanographic and Atmospheric Administration's (NOAA) ECOHAB program through grant NA16OP1440 and by the US Environmental Protection Agency's (EPA) Science to Achieve Results (STAR) program through grant R-82937001. This work has not been reviewed by NOAA or EPA and therefore does not necessarily reflect their views and no official endorsement should be inferred.

\section{LITERATURE CITED}

Boynton W, Kemp W (1985) Nutrient regeneration and oxygen consumption by sediments along an estuarine salinity gradient. Mar Ecol Prog Ser 23:44-55

Cable J, Burnett W, Chanton J, Weatherly G (1996) Estimat- 
ing groundwater discharge into the northeastern Gulf of Mexico using ${ }^{222}$ radon. Earth Planet Sci Lett 144:591-604 Clark D, Flynn K (2002) N-assimilation in the noxious dinoflagellate Hetersigma carterae (Raphidophycaea): dependence on light, N-source and physiological state. J Phycol 38:503-518

Cochlan W, Harrison W, Denman K (1991) Diel periodicity of nitrogen uptake by marine phytoplankton in nitrate-rich environments. Limnol Oceanogr 36:1689-1700

Corbett D, Chanton J, Burnnett W, Dillon K, Rutowski C (1999) Patterns of groundwater discharge into Florida Bay. Limnol Oceanogr 44:1045-1055

Cullen J (1985) Diel vertical migration by dinoflagellates; roles of carbohydrate metabolism and behavioral flexibility. Contrib Mar Sci 27:135-152

Cullen J, Horrigan S (1981) Effects of nitrate on diurnal vertical migration, carbon to nitrogen ratio and photosynthetic capacity of the dinoflagellate Gymnodinium splendens. Mar Biol 62:81-89

Darrow BP, Walsh JJ, Vargo GA, Masserini RT, Fanning KA, Zhang JZ (2003) A simulation study of the growth of benthic microalgae following the decline of a surface phytoplankton bloom. Cont Shelf Res 23:1265-1283

Dragovich A, Finucane JH, May BZ (1961) Counts of red tide organisms Gymnodinium breve and associated oceanographic data from Florida west coast, 1957-1959. US Fish \& Wildl Serv Spec Sci Rep Fisheries No. 369

Eppley R, Rogers J, McCarthy J, Sournia A (1971) Light/dark periodicity in nitrogen assimilation of marine phytoplankters Skeletonema costatum and Coccolithus huxleyi in Nlimited chemostat cultures. J Phycol 7:150-154

Fanning KA, Breland JA, Byrne RH (1982) Ra-226 and Rn-222 in the coastal waters of West Florida-high-concentrations and atmospheric degassing. Science 215:667-670

Flynn KJ, Clark DR, Owens NJ (2002) Modelling suggests that optimization of dark nitrogen-assimilation need not be a critical selective feature in phytoplankton. New Phytol 155: 109-119

Harrison W (1976) Nitrate metabolism of the red tide dinoflagellate Gonyaulux polyedra Stein. J Exp Mar Biol Ecol 21:199-209

Katz BG, Bohlke JK (2000) Monthly variability and possible sources of nitrate in ground water beneath mixed agricultural land use, Suwannee and Lafayette Counties, Florida. US Geological Survey: Florida Department of Environmental Protection, Tallahassee, FL

Kamykowski D (1981) Laboratory experiments on the diurnal vertical migration of marine dinoflagellates through temperature-gradients. Mar Biol 62:57-64

Kamykowski D, Yamazaki A (1997) A study of metabolisminfluence orientation in the diel vertical migration of marine dinoflagellates. Limnol Oceanogr 42:1189-1202

Kamykowski D, Milligan EJ, Reed RE (1998a) Biochemical relationships with the orientation of the autotrophic dinoflagellate Gymnodinium breve under nutrient replete conditions. Mar Ecol Prog Ser 167:105-117

Kamykowski D, Milligan EJ, Reed RE (1998b) Relationships between geotaxis/phototaxis and diel vertical migration in autotrophic dinoflagellates. J Plankton Res 20:1781-1796

Kristiansen S (1983) The temperature optimum of the nitrate reductase assay for marine phytoplankton. Limnol Oceanogr 28:776-780

Liu G, Janowitz G, Kamykowski D (2001a) A biophysical model of population dynamics of the autotrophic dinoflagellate Gymnodinium breve. Mar Ecol Prog Ser 210:101-124

Liu G, Janowitz G, Kamykowski D (2001b) Influence of environmental nutrient conditions on Gymnodinium breve (Dinophyceae) population dynamics: a numerical study. Mar Ecol Prog Ser 213:13-37

MacIsaac J (1978) Diel cycles of inorganic nitrogen uptake in a natural phytoplankton population dominated by Gonyaulax polyedra. Limnol Oceanogr 23:1-9

McCarthy J, Goldman J (1979) Nitrogenous nutrition of marine phytoplankton in nutrient-depleted waters. Science 203: 670-672

Morel F (1987) Kinetics of nutrient uptake and growth in phytoplankton. J Phycol 23:137-150

Nixon SW (1981) Remineralisation and nutrient cycling in coastal marine systems. In: Neilson BJ, Cronin LE (eds) Estuaries and nutrients. Humana Press, Clifton, NJ, p 111-138

Reed RE (2000) Effects of natural irradiance flucuations on Gymnodinium breve (Karenia brevis) and Thalassiosira pseudonana and hydrographic structure associated with persistent Gymnodinium breve (Karenia brevis) subsurface accumulations with implication for red tide patch formation. PhD dissertation. North Carolina State University, Raleigh, NC

Rutkowski C, Burnnett W, Iverson R, Chanton J (1999) The effect of groundwater seepage on nutrient delivery and seagrass distribution in northeastern Gulf of Mexico. Estuaries 22:1033-1040

Shanley E, Vargo G (1993) Cellular composition, growth, photosynthesis, and respiration rates of Gymnodinium breve under varying light levels. In: Smayda TJ (ed) Toxic phytoplankton blooms in the sea. Elsevier, New York, p 831-836

Sinclair GA, Kamykowski D, Milligan E, Schaeffer B (2006) Nitrate uptake by Karenia brevis. I. Influences of prior environmental exposure and biochemical state on diel uptake of nitrate. Mar Ecol Prog Ser 328:117-124

Smayda T (1997) Harmful algal blooms: Their ecophysiology and general relevance to phytoplankton blooms in the sea. Limnol Oceanogr 42:1137-1153

Steidinger K, Haddad K (1981) Biological and hydrographic aspects of red tides. Bioscience 31:814-819

Steidinger KA, Vargo GA, Tester PA, Tomas CR (1998) Bloom dynamics and physiology of Gymnodinium breve with emphasis on the Gulf of Mexico. In: Anderson DM, Cembella AD, Hallegraef GM (eds) Physiological ecology of harmful algal blooms. Springer-Verlag, Berlin, p 133-153

Tester PA, Steidinger KA (1997) Gymnodinium breve red tide blooms: Initiation, transport, and consequences of surface circulation. Limnol Oceanogr 42:1039-1051

Vargo G, Shanley E (1985) Alkaline phosphatase activity in the red tide dinoflagellate Ptychodiscus brevis. PSZN I: Mar Ecol 6:251-264

Walsh J, Steidinger K (2001) Saharan dust and Florida red tides: the cyanophyte connection. J Geophys Res 106: $11597-11612$

Wilson W (1966) The suitability of sea-water for the survival and growth of Gymnodinium breve (Davis); and some effects of phosphorus and nitrogen on its growth. Fla Board Conserv Mar Lab Prof Pap Ser No 7

Yamazaki A, Kamykowski D (2000) A dinoflagellate adaptive behavior model: response to internal biochemical cues. Ecol Model 134:59-72 